\title{
Au pair-strategier
i danske familier \\ - privat husarbejder eller maternalistisk mikrostyring
}

\section{AF Helle Stenum}

Antallet af isar filippinske au pairer $i$ danske familiev er vokset meget de senere air, og au pairen er som midlevtidig migrant formelt underlagt en rakke begransninger. I lovgivningen er bun defineret som: Ikke en billig hushjalp men som en del af familien. Hvordan forvaltes og fortolkes den asymmetriske magtrelation i hjemmet mellem migrantkvinden og hendes (oftest kvindelige) arbejdsgiver $i$ den konkrete dagligdag på det, man kunne kalde det voksende arbejdsmarked for privatbetalt live-in busarbejde?

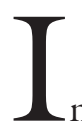

nden for de senere år er der sket en eksplosiv vakst i antallet af især filippinske au pairer i dobbelt-karrierefamilier i middel- og overklassen i Danmark. Fokus for denne artikel er den position, der skabes i kombinationen af au pairens migrantstatus, fastsat af politisk bestemte migrationsreguleringer og den konkrete relation mellem au pair-ansat og au pair-arbejdsgiver.

Artiklen vil på baggrund af forskning i styring af migration og leve- og arbejdsforhold for au pairer i Danmark, ${ }^{1}$ undersøge det felt, som au pairer arbejder i - det private hjem - som ramme for et særligt arbejdsmarked, der er defineret uden for de almindelige arbejdsmarkedsregler, lønfastsættelser og overenskomstforhandlinger, men som samtidig er konstitueret i en fundamental asymmetrisk magtrelation mellem arbejdsgiver og -tager. Endvidere er relationen mellem au pair og værtsfamilie ofte karakteriseret ved en grad af gensidig afhængighed og en ofte intim og følelsesladet re- 
lation i et privatiseret felt af kønnet hus- og omsorgsarbejde.

I min empiriske undersøgelse ${ }^{2}$ var det $\mathrm{i}$ langt de fleste tilfælde kvinden i værtsfamilien, som påtog sig arbejdslederrollen og havde den txtteste kontakt med den kvindelige husarbejder/au pair. Den mest betydningsfulde og dominerende relation i arbejdsrelationen sker således ofte som en kvinde-til-kvinde relation $i$ et felt af privat kønnet hus- og omsorgsarbejde. Endvidere er der oftest tale om relationer mellem 'hvide,' etniske majoritetskvinder/værtsfamilier og 'brune' etniske minoritetskvinder/au pairer.

I litteraturen findes forskellige beskrivelser af strategier, der ofte karakteriserer relationen mellem den kvindelige arbejdsgiver og hendes ansatte husarbejder.

Jeg har valgt at fokusere på to hovedstrategier, som er fremanalyseret i andre nationale kontekster end den danske: 'ligesom arbejdskraft'-strategien (Sollund 2010) og 'ligesom familie'- eller 'del-af-familien'strategien, der rummes i begreber omkring 'emotional labour' og maternalisme (Rollins 1985, Anderson 2002, Parrenas 2001, Ardano 2003, Romero1992/2001, Gutierrez-Rogriguez 2010, Glenn 1992, Hondagneu-Sotelo 2001). Ud fra en umiddelbar vurdering kunne man have en antagelse om, at den nationale eller regionale kontekst for migranters husarbejde spiller en rolle for hvilke strategier, der anlægges i relationen mellem arbejdsgiver og husarbejder.

Jeg stiller spørgsmålet, om disse strategier giver mening som begrebsliggørelse af relationen mellem au pair og værtsfamilie i en dansk kontekst på baggrund af en analyse af kvalitative interviews med au pairer og værtsfamilier.

\section{DEFINITIONER OG DEFINITIONSKAMP}

Udlændingeservices vejledning til indgåelse af au pair-kontrakt understreger, at "au pair-personen ikke er en billig hushjælp," og "Au pair-personens deltagelse i værtsfamiliens husholdning anses ikke for arbejde." 3

Det synes således at være vigtigt at definere au pairen som det, hun ikke må være: billig husarbejdskraft. Hun må ikke være billig, hvilket peger på den omstændighed, at hun făr en løn, der ikke kan forsvares, hvis hendes 'hjælp i huset' var defineret som arbejde. Men hun må heller ikke være en dyr hushjxelp - dvs. lønnet efter en i andre sammenhænge acceptabel eller rimelig skala, for hendes hjæelp må ikke - billig eller dyr - defineres som arbejde, for så ville hun kunne sælge sin arbejdskraft andre steder end i det private hjem og være berettiget til en egentlig arbejdstilladelse.

'Arbejde' og arbejdsmarked er på den ene side ikke tilstede i de formelle lovgivningsmæssige rammer, men på den anden side praktiseres og i visse tilfælde administreres au pair-ansættelsen dog alligevel som et arbejdsforhold.

Au pairens opholdstilladelse hviler på forestillingen om et 'kulturelt udvekslingsophold'4 og om at være en del af familien. Familien som social forståelsesramme er central: "Au pair-personen skal under hele au pair-opholdet indtage en familiær stilling hos familien." 5 Der er altså ikke tale om en gxst, eller en ansat, men om en person med en familiær rolle, hvilket i Udlændingeservices retningslinjer indebærer, at hun skal udføre "huslige pligter," at hun skal bo hos sin værtsfamilie, og at hun er "live-in" (fx Anderson 2000).

De centrale styringsmekanismer relateret til migrationsreguleringen på dette særlige arbejdsmarked for betalt privat husarbejde er således for det første, at au pair-husarbejderen skal bo sammen med familien, hvilket forstærker afhængigheden og vanskeliggør adskillelse mellem arbejde og fritid og mellem arbejde og hjem. For det andet er hendes arbejdsplads - det private hjem - karakteriseret ved at være et ikke-offentligt sted, et lukket rum og som oftest en ramme omkring en ene-arbejdsplads, hvilket både af- 
skærer hende fra kolleger og forbindelse til et offentligt rum (Constable 1997, Anderson 2002, Stenum 2008).

Da hun ikke er udstyret med en arbejdstilladelse, kan hun derfor ikke søge arbejde på det almindelige arbejdsmarked og er dermed fastholdt som au pair-arbejdskraft.

Endelig er opholdstilladelsen midlertidig, og den er bundet til en bestemt værtsfamilie. Det vil sige, at au pairen ikke kan skifte familie uden også at søge om fornyet opholdstilladelse, hvilket igen medfører en stærk afhængighed af arbejdsgiveren.

I forlængelse af denne forståelse af au pairens position vil jeg $\mathrm{i}$ det følgende se nærmere på, hvilke forestillinger og rationaliseringer, der er på spil i den konkrete relation mellem au pair og værtsfamilie, som de er kommet til udtryk i min undersøgelse blandt de 24 au pairer og 6 værtsfamilier (fire kvinder og to mænd), som jeg interviewede i 2008 .

\section{HJEMMET SOM EN SÆRLIG}

\section{ARBEJDSPLADS FOR KØNNET ARBEJDE}

At au pairens arbejde foregår i det private hjem er ikke uden betydning i nutidens definitionskamp, ligesom det faktum, at au pairen oftest kommer fra den økonomisk fattige del af verden og tilhører en ikkevestlig minoriseret etnisk gruppe, heller ikke er det. At det arbejde, au pairen udfører, stadig er kønnet som kvindearbejde er selvfølgelig også betydningsfuldt.

Helma Lutz (2008) har beskæftiget sig indgående med migranters husarbejde i Europa, og hun advarer mod at betragte husog omsorgsarbejdsmarkedet som “just another labour market." Ifølge Lutz er hus- og omsorgsarbejdsmarkedet karakteriseret ved:

- Den intime karakter i den sociale sfære som arbejdet udføres i

- Den sociale konstruktion af husarbejde (og børnepasning) som kvindearbejde

- Den specielle følelsesmæssige og personlige relation mellem ansat og arbejdsgiver, og en ofte høj grad af gensidig afhængighed - Logikken i og karakteren af selve arbejdet, der udføres. (Lutz 2008)

Andre (Romero 1992, Glenn 1992, Parrenas 2002, Guitterez-Rofriguez 2010) har analyseret migranters husarbejde 6 med udgangspunkt i Hochschilds begreb om "emotional labour" (Hochschild 1983). Emotionelt arbejde i modsætning til fysisk arbejde, indebærer, at følelser, personlig kontakt og omsorg bliver en del af arbejdsforholdet og typisk arbejde, der er kønnet som kvindeligt. Betalt arbejde i hjemmet især som live-in - vil indeholde elementer af emotionelt arbejde, og i forestillingen om at være en del af familien ligger en forventning om en følelsesmæssig relation og investering. Samtidig er magtrelationen i arbejdsforholdet sløret.

Maternalisme som en form for kønnet, klasserelateret og racialiseret 'emotional labour' tilbyder en begrebsliggørelse af relationen mellem den kvindelige arbejdsgiver og den kvindelige ansatte betalte husarbejder.

Maternalisme er ifølge Rollins (1985) grundet i paternalismens personlige relation mellem herskab og tjenestefolk, som er videreført i anakronistisk form i relationen mellem arbejdsgiver og husarbejder. For Rollins er det af afgørende betydning, at arbejdsforholdet praktiseres mellem kvinder.

Relationen er ifølge Rollins grundlæggende baseret på et over- og underordningsforhold situeret $\mathrm{i}$ en familiær ramme, der trækker på elementer som omsorg, envejs gavegivning, disciplinering etc.: "The maternalism dynamic is based on the assumption of a superordinate-subordinate relationship. While maternalism may protect and nurture, it also degrades and insults” (Rollins 1985:186).

Mens Rollins anser paternalisme og maternalisme som forskellige former for magtrelationer i reproduktionen af klasse- og racialiserede hierarkier, ser Anderson (2000) 
maternalisme som en magtrelation, der først og fremmest reproducerer patriarkatet og først $\mathrm{i}$ anden omgang producerer forskelle mellem kvinder. Ardano (2003), der har forsket i husarbejdere og deres arbejdsgivere blandt familier i Filippinerne, hvor det etniske forskelshierarki ikke er til stede, fordi begge parter tilhører samme etniske gruppe, karakteriserer maternalisme som "embodied in the mistress-maid relations, reproduces the inequitable, class-gender structure, in which middle class women subdordinated by their gender, delegate the unglamorous domestic work to poor women for low wages" (Ardano 2003:154).

Hun betegner maternalisme som "falsk generøsitet”, der tilslører udbytningen af arbejdskraften og fratager husarbejderen hendes egen kontrol over tid, rum og relationer (ibid.).

Elementer i maternalistisk indskrevne relationer kan bl.a. være forventninger om, at husarbejderen investerer i 'mothering' for arbejdsgiverens børn, at hun indgår i en ikke-gensidig omsorgsrelation til arbejdsgiveren ved at lytte til personlige beretninger uden at modsige, at hun er villig til at fortælle personligt om sit eget liv og modtage råd og vejledning, at hun udviser taknemmelighed i den envejs-gavegivning, som ofte erstatter løn eller lønstigninger og at hun er villig til at tilfredsstille arbejdsgiverens behov for gennem denne (ofte eneste) personlige relation til et menneske med etnisk minoritetsbaggrund, marginaliseret migrantstatus og globaliseret klasseforskel at styrke deres selvbillede som gode antiracister (Romero 1992) eller hensynsfulde verdensborgere/ulandsbistandsdonorer.

Min brug af maternalismebegrebet, trækker på 'familiserede' og kønnede personlige relationer samt på forestillingen om det kønnede og racialiserede hus- og omsorgsarbejde som ramme om et omfattende repertoire af adfærdskoder og følelsesmæssige investeringer $\mathrm{i}$ den asymmetriske magtrelation.

'Emotional labour'- og maternalismestu- dierne har i overvejende grad fokuseret på migranters husarbejde i USA og Europa med andre koloniale, kønsmæssige og klassemæssige relationer og traditioner end dem, der er gxldende i de nordiske lande. Men i en tid hvor migranters husarbejde også bliver en synlig størrelse i Norden, er det relevant at undersøge den særlige intersektion mellem køn, klasse, etnicitet og migrantstatus, som leves og erfares i au pairrelationen.

En anden strategi for håndtering af den konkrete au pair-relation i det private hjem er først og fremmest at fokusere på arbejdsforholdet og dermed forsøge at etablere en afstand til den gensidige følelsesmæssige investering i en familierelation, en strategi jeg kalder 'ligesom arbejdskraft'-strategi.

Sollund (2010) har analyseret det, hun kalder "måder at legitimere hushjælp" blandt norske au pair-værtsfamilier på baggrund af kvalitative interviews, og hun har fundet en gennemgående tendens til i højere grad at definere au pairen som en arbejdskraft og et voksent menneske end som en del af familien, hvilket tilsyneladende fungerer bedre i distanceringen fra opfattelsen af, at au pairen fungerer som en billig tjener. Det etablerer tilsyneladende lettere en forestilling om lighed med au pairen, som er vigtig i Norge for at kunne opretholde legitimiteten omkring ordningen, og som også gør arbejdsgiverrollen mindre kompliceret, i og med at værtsfamilien kan stille krav og forvente, at de opfyldes i en køb-salg/varerelation uden at skulle investere i en mere omfattende følelsesmæssig 'familie-pakke.'

\section{'LIGESOM ARBEJDSKARFT'-STRATEGI: AFSTAND OG LIGHED}

En af de to mænd blandt mine værtsfamilie-informanter gav udtryk for en strategi, der ligner den norske 'ligesom arbejdskraft'-strategi. For ham og hans kone var det vigtigt at signalere, at au pairen ikke skulle være en del af familien. De foretrak 
for eksempel at holde ansættelsessamtaler med au pairer, der allerede var i Danmark det vil i praksis sige med au pairer, der gerne ville skifte familie.

"Det afspejler så også modsat, at vi sådan set ikke leder efter et nyt familiemedlem. Det er noget, vi gor meget klart fra starten, nair vi taler med mulige au pair-piger, det er, at vi spiser sammen maiske en gang om ugen, vi ses selvfolgelig lobende, men det er ikke saidan, at bun rigtig er en integrevet del af familien.” (Anders)

Her lægges eksplicit afstand til forestillingen om, at au pairen skal være et nyt familiemedlem, hvilket afspejles i normen for samvær mellem værtsfamilien og au pairen; et ugentligt måltid, hvilket vil sige begrænset følelsesmæssig investering mellem de voksne. Hvorvidt værtsforældrene forventer en passende følelsesmæssig investering fra au pairens side i relationen til børnene nævnes ikke eksplicit, men implicit defineres også denne relation om ikke ud af, så på afstand af 'del af familien'-forestillingen.

Man kan således have en antagelse om, at 'del af familien' eller 'ligesom familie' først og fremmest handler om relationen mellem de involverede voksne, mellem værtsarbejdsgiveren og au pairen.

Om køn - det forhold at begge forældre tilstræbte en ligelig fordeling af arbejdslederansvaret - har spillet en rolle i deres valg af, hvordan relationen til au pairen skulle defineres er svært at vurdere i det konkrete tilfælde, men det ligner de mønstre omkring selvoplevet kønsligestilling og legitimeringsstrategi, som Sollund beskriver.

Hos den omtalte værtsfamilie var familiens bolig fysisk indrettet således, at au pairen havde en separat bolig med egen indgang, køkken, bad osv., så hun rent faktisk havde mulighed for at fungere uafhængigt af resten af familien, når hun havde fri. Endvidere accepterede de, at de skiftende au pairer arbejdede ved siden af.
Der blev således også skabt en fysisk afstand mellem au pair og arbejdsgiverfamilie, som brød med live-in-konceptets implicitte intimitet.

Uden opfordring bevægede Anders sig selv ind på den moralske økonomi i arrangementet og rationaliserede igen ud fra en arbejdskraftsforståelse, der dog blev understøttet af skattetrykket, som en implicit retfærdiggørelse af den lave løn:

"Er det den rigtige balance, vi har ramt, og den måde, vi bruger den her ordning på, er den moralsk forsvarlig? (...) .. hvad betyder det at deres lon ligger på en tredjedel af, hvad en mindstelon vil gore herhjemme, er det uacceptabelt? (...) ..., det er klart, at skat på arbejde, og derved prisen på arbejde, er blevet for hoj herhjemme, og vi mangler den der mellemordning, som gor, at man kan tilgodese behovet for praktisk hjelp og samtidig behovet, der er for nogle mennesker, for at tjene nogle penge. Det er selvfolgelig ikke meget, hun tjener, men både relativt set og sådan set også for at vere $i$ Danmark, synes jeg, at det er en okay ordning." (Anders)

At au pairens løn er lav anerkendes af Anders og relateres først til skattetrykket i forståelsen 'vi betaler så meget i skat, så vi har ikke råd til at give en højere løn' og i næste omgang uklart til noget 'relativt' og til det at være i Danmark, som tilsyneladende refererer til, at au pairen er migrant fra et fattigt land, dvs. relativt får hun noget ud af lønnen, og det er derfor, hun er her. Den globale ulighed er hermed kommet på banen som rationalisering og retfærdiggørelse af den lave løn.

På trods af at der i mine interviews findes eksempler på, at au pairens position i det private hjem klart kan karakteriseres direkte som et tjenestepigeforhold, hvor den kvindelige arbejdsgiver fx omtaler au pairen over for andre som sin 'maid,' så er der i danske værtsfamilier (afspejlet i mine interviews både med au pairer og værtsfamilier) dog noget, der tyder på, at rationaliserin- 
gen eller legitimeringen af den asymmetriske relation i højere grad vægter 'del af familien'-konstruktionen.

Dette kunne tyde på en forskel mellem rationaliseringerne i Norge (Sollund 2010) og i Danmark.

En af mine arbejdsgiver-informanter refererede eksplicit til forskellen mellem Danmark og Norge gennem en tidligere filippinsk au pair, som hun havde skaffet en ny værtsfamilie i Norge, men samtidig efterfølgende inviteret med til juleaften i Danmark.

"Så kom hun her ned, og vi havde juleaften, og mine foreldre var her, og så spurgte min mor:

"Nä, hvordan gàr det sà, er du glad for det, er det fint?" Så sagde bun: "It's a nice family but I'm not really the same part of the family." Altså, det betød rigtig meget for hende." (Hanne)

Hermed får Hanne samtidig fortalt historien om, at au pairen bør være en del af familien og på den rigtige måde. Ikke mindst fordi det betyder så meget for au pairen. Omsorgselementet i værtsmorrollen og normen omkring integration i familien fremhæves som betydningsfuldt.

\section{LigesOM FAMILIE: TÆTHED OG ENHED}

Nogle af de interviewede værtsarbejdsgivere gjorde meget ud af, at au pairen skulle være en del af familien.

Hanne, som havde haft mange au pairer ansat, lagde megen vægt på, at au pairen skulle integreres $\mathrm{i}$ familien og forsøgte efterfølgende at holde forbindelsen med de au pairer, der holdt op. Nogle af dem blev gift i Danmark, og hun blev gudmor til deres børn. Hun understregede vigtigheden af omsorgen for au pairen, og det at de spiste sammen om aftenen.

Derimod brød hun sig eksplicit ikke meget om, at der gik for meget arbejdsgiverarbejdstager i relationen. Om den første au pair, der havde fået lov til at bo sammen med sin søster i nærheden og derfor kom om morgenen og gik sidst på eftermiddagen, sagde hun:

"Hun kom om morgenen, og så nàr vi kom hjem, så var hun gået igen, og vi sà hende nermest ikke. Og jeg synes, det er vigtigt, at man har de der måltider sammen. Man fär sådan et 'kommer og gair' og er der sammen i forskellige sammenheng. Det blev lidt for meget en arbejdskraft, der kom og gik, og ikke en, der overhovedet blev integreret i familien.”

(Hanne)

I modsætning til Anders er det for Hanne i hendes forestillinger om au pair-forholdet ikke tilstrækkeligt, at au pairen udfører husarbejdet i arbejdstiden og derefter forlader hjemmet. Den omtalte au pair brød med live-in-kontrakten ved at 'komme og gå'. Der blev ikke udtrykt kritik af det arbejde, hun udførte, men af den manglende vilje til integration i familien, af den manglende vilje til følelsesmæssig investering $i$ at 'være en del af familien'.

På spørgsmålet om Hanne mindedes, at hun havde haft konflikter med nogle af sine au pairer, nævnte hun konflikter omkring løn med den samme au pair:

"Jeg havde med hende den forste. Der havde jeg lidt konflikter. Det tror jeg igen var affodt af, at det var saidan et merkeligt arbejdsgiverarbejdstager-forhold (...) .. jeg var saidan lidt irriteret, fordi hun kom heer anden dag og konfronterede mig med, nu var der en veninde, der havde fået 100 kroner i tilskud til et eller andet. Altsä, hun ville bele tiden forbandle lon. Og det har jeg gjort meget ud af med dem, jeg har haft efterfolgende at sige, det her er lonnen, og det er det I fair, og vil I det eller vil I ikke? For det skal I ligesom vide, er I ikke interesseret, så find jer helleve noget andet. For jeg gider ikke, at nair I skal vere en del af familien her, at sidde her hver anden aften og hore på, at nu har I børt om en ovre pà en anden vej, der fär 200 kroner mere." (Hanne)

Den uønskede relation mellem den kvinde- 
lige arbejdsgiver og au pairen betegnes her som et "mærkeligt arbejdsgiver-arbejdstager forhold", dvs. at disse roller er forstyrrende for familierelationerne og skaber konflikter. Forholdet til au pairen defineres eksplicit i modsætning til arbejdsgiver-arbejdstager-relationen, hvor det for Anders var et spørgsmål om at definere au pair-relationen i modsætning til 'del-af-familie'-relationen.

Det lader til, at Hanne gennem den første au pair-relation var blevet klar over, hvilken rolle hun selv ville spille i relationen - og det skal ikke være arbejdsgiverens det skal snarere være som den, der inviterer ind $\mathrm{i}$ familien, men på meget bestemte præmisser.

En anden kvindelig værtsfamilie-informant betegnede au pairens plads $\mathrm{i}$ familien som en storesøsters:

"På det plan, der hedder hjelp, der synes jeg, at det er en behagelighed. Altsa, vi har et lille hus, og vi er ikke saidan spendt meget hàrdt for. Det er som at have en storesoster $i$ familien, som kan gå til hainde og hjalpe til. Det synes jeg er en kampehjalp.... Så derfor kan jeg godt lide den ordning." (Ida)

Au pairen installeres her i storesøsterrollen - som en der stadig er underlagt det familiære hierarki med underordnede magtrelationer til mor og far, og som en der går til hånde med det kønnede husarbejde og derfor også selv er af et 'passende' køn. Det er ikke positionen som 'storebror,' der tilbydes.

Den anden mandlige informant, som i øvigt ret usædvanligt, havde påtaget sig rollen med at være arbejdsleder for au pairen formulerede sig anderledes: "Det er et menneske, der indgår i familien” (Rasmus). Men Ida og Rasmus var fælles om at ville udvide familien til at omfatte au pairen.

At være en del af familien kunne bl.a. indebære regler for au pairens fritid, som ligner de regler, der stilles op for husets teenager; beskrevet af au pair-informanterne som bl.a. at værtsfamilien skal vide, hvornår au pairen er ude, hvem hun er sammen med, evt. forbud mod at overnatte udenfor huset mv. Det kunne være en forventning om en særlig intimitet og fortrolighed mellem den kvindelige arbejdsgiver og au pairen især omkring au pairens livshistorie, familie og kærester, men også løbende beretninger fra den kvindelige arbejdsgiver om problemer med xgtemanden, graviditeter, sygdomme, problemer på arbejdspladsen mv. Det kunnen også være noget med tiltaleformer (Rollins 1985), og noget med at undgå at benævne relationen til au pairen som et underordningsforhold. Og det gjaldt både i forhold til, hvad værtsfamilien kalder au pairen, og hvad au pairen kaldte værtsfamilien.

Hanne sagde om au pairens tiltale af hende:

"Da vi fik Bridget fra Singapore, var noget af det forste, hun spurgte mig om, om hun måtte kalde mig for Mam. Så måtte jeg forklare, at, nej, det ma du ikke. Det gor vi bare ikke her, der hedder jeg Hanne, og du hedder Bridget, og sådan er det $i$ Danmark, og ellers bliver det misforstået, så tror de, jeg er en hvid slavepisker, hvis du går og kalder mig for Mam, sà det må du love mig, at du aldrig gør.” (Hanne)

Hanne distancerer sig her fra betegnelsen 'hvid slavepisker' og 'Mam' om sig selv, der på hver sin måde udtrykker den asymmetriske magtrelation i forholdet, og fortæller hvordan hun instruerer au pairerne $i$ at benytte fornavne, som signalerer lighed og intimitet. At hun heller ikke opfatter sig selv som 'Mam' eller 'hvid slavepisker' er implicit. I øvrigt er det også interessant, at hun her italesætter sin egen 'hvidhed,' selv om det foregår i forbindelse med en negativ afgrænsning. Dette tyder på at det kolonialt ladede billede af den hvide 'mistress' og den brune 'maid' er inkluderet i hendes forestillinger om den relation, hun praktiserer til daglig med sin betalte migranthusarbejder.

Rasmus, der på den ene side understre- 
gede, at han ikke "skammede sig over at have en au pair", men på den anden sagde, at han ikke på sin arbejdsplads havde fortalt om au pairen, refererede til, at hans børn havde kaldt au pairen for 'tjener,' og at dette ikke var acceptabelt.

\section{"Vi siger, at det er vores au pair-pige. Vi har} gjort meget ud af det. Vores mindste havde $i$ en periode fået den opfattelse at: "Det er min tjener". Det er vi meget obs. på. (...) Vi vil have at bornene stadigvek hjelper til. (...) Så den måde, vi omtaler hende, er, at det er vores au pair, som vi er heldige at have. At hun kan vare med til at vores familie fungerer." (Rasmus)

Hvor Hannes bestræbelser i høj grad handlede om at styre betegnelsen af hende selv og den position hun indtog gennem afgrænsning af, hvad hun IKKE var; en hvid slavepisker, handlede det for Rasmus om at styre betegnelsen af au pairen - og igen som noget hun IKKE er eller kaldes; tjener.

I begge tilfælde forankres modpolen til tjener og slavepisker i familien som enhed; au pairen er del af familien, en der hjælper familien eller er som en storesøster.

\section{"Men inden for denne fortolkning af lighed praktiseres der samtidig en etnisk udvalgelse af au pairen:}

"Der er jo ingen tvivl om, at de her filippineve er blevet populare, fordi de er arbejdsomme. (...) [Man] slipper for nogle af de andre problemer som jeg har hort om fra andre, der har haft andre nationaliteter"." (Rasmus)

Bestræbelserne på at fastholde en omgangsform, som signalerer ligestilling og familiære relationer i stedet for over- og underordning ses her som vigtige for familierne. De au pairer jeg interviewede, omtalte ofte den kvindelige arbejdsgiver for 'host mother,' som igen understregede familiekonstruktionen, men mange refererede også til 'the woman' eller 'the girl.'

Betegnelsen "au pair-pige" er tillige med til at fastholde au pairen i en familiær og in- fantiliseret position inden for en familie som et barn, der skal passes på. Når denne 'pige' så viser sig selv at være mor, kompliceres rollerne. En af arbejdsgiverinformanterne havde foræret au pairen en ekstra billet til en tur til Filippinerne, da det gik op for hende, at au pairen havde forladt sit etårige barn. Dette kan ses som en maternalistisk envejs gavegivning og et forsøg på at overtrumfe betydningen eller ubehaget ved den symmetriske mor-mor-relation.

Af andre former for envejs gavegivning kan nævnes flybilletter til weekendture rundt i Europa, store julegaver, aflagt tøj, legetøj mv. som trækker på emotionelle og familiserede relationer til erstatning for kravs- og rettighedsbaseret betaling.

\section{KONKLUSION}

Overordnet positionerer de to forskellige strategier både arbejdsgiver og au pair forskelligt.

Hvor Anders i sit arbejdsgiver-arbejdstagerforhold placerer sig selv $\mathrm{i}$ arbejdsgiverrollen mere end i 'værtsfar'-rollen, så placerer Hanne sig med prioriteringen af familiseringen af relationen sig selv i 'værtsmor'rollen. Begge relationer udtrykker asymmetriske magtrelationer, men hvor den ene position nedtoner den følelsesmæssige investering og opprioriterer relationen som et arbejdsforhold med tilhørende adskillelse af arbejde og privatliv og forhandlinger om arbejds- og lønvilkår ud fra en arbejdskraftsbetragtning, så er den anden position karakteriseret af, at løn- og arbejdsforhold er tabuiseret, at der forventes en stor følelsesmæssig investering i relationen mellem de voksne, samtidig med at au pairen er placeret $\mathrm{i}$ et familiært rum, hvor hun kan indtage rollen som storesøster.

Såvel 'ligesom arbejdskraft'-strategien som 'ligesom familie'-strategien fungerer sjældent isoleret i værtsfamiliernes fremstilling, men snarere $\mathrm{i}$ et kompleks med andre tværgående rationaliseringsstrategier omkring 'othering,' 'kønsligestilling' og 'win- 
win'-forestillinger, som pladsen her ikke rækker til at analysere nærmere.

Men på baggrund af det empiriske materiale om au pair-værtsfamilie-relationer i en dansk kontekst, giver det som en start mening at begrebsliggøre relationerne og positionerne ved hjelp af disse to strategier. Der er dog især omkring maternalisme-begrebet behov for en yderligere tilpasning, der kan gøre det følsomt over for den lokale kontekst, hvor for eksempel forestillingen om 'lighed' som 'enhed,' den tilstræbte og oplevede kønsligestilling omkring husarbejdet og betydningen at skulle undgå positioner som hvid slavepisker og tjener, fortolkes ind.

Det kunne se ud som om, den norske og den danske kontekst adskiller sig fra hinanden, når det handler om valg af strategi $\mathrm{i}$ den enkelte familie.

Myndighedernes definition af au pairen er karakteriseret ved en række markeringer af, hvad au pairen ikke er; hun arbejder ikke, hun er ikke en arbejder, hun får ikke rigtig løn, hun er ikke en arbejdsmigrant. Hun er derimod en del af familien.

Det positionerer hende ikke automatisk som offer, og hun har mulighed for at handle og forhandle inden for denne ramme, men det placerer hende i den lette ende af en meget tung asymmetrisk magtrelation, og med få muligheder for at ændre rammerne.

Når relationen i familierne overvejende praktiseres 'ligesom familie' vil den maternalistiske mikrostyring være med til at fastholde og stabilisere privilegierne i dette etablerede sociale hierarki og dermed også bane vejen for en fortsat ekspansion af det legale ikke-anerkendte arbejdsmarked for ikke-anerkendt betalt, privat hus- og omsorgsarbejde i Danmark, hvor en 'ligesom arbejdskraft'-praksis i højere grad ville kunne bevæges hen mod ændring af rammerne, anerkendelse af au pair-ansættelse som et arbejdsforhold og dermed flere handlemuligheder for migranthusarbejderen.

\section{Noter}

1. Kvalitative interviews foretaget i perioden oktober 2007-juni 2008 med:

. 24 au pairer i Storkøbenhavn, heraf 21 fra Filippinerne, 1 fra Rusland, 1 fra Uganda og 1 fra Nepal. Af de 24 au pairer havde 3 afsluttet au pair-opholdet, men opholdt sig stadig i Danmark og heraf var 1 uden opholdstilladelse og 2 med andre opholdstilladelser end som au pair. Alle de interviewede var kvinder. Informanterne blev kontaktet ad mange forskellige kanaler; internettet, loppemarkeder, sprogskoleklasse, kirker m.v.;

. 6 værtsfamilier i Storkøbenhavn, der har haft mellem 2 og 8 au pairer ansatte i hjemmet.

. 8 aktører, der enten som myndighedsperson eller civilsamfundsperson (foreninger, kirker o.a.) har haft berøring med au pairs i Danmark. Det drejede sig bl.a. om en embedsperson i Udlændingeservice, to præster og 3 centralt placerede foreningsaktive indenfor det filippinske og kirkelige foreningsmiljø.

2. Se forrige note.

3. Udlændingeservice: AUl:

Ansøgningsskema/Application Form. Ansøgning om opholdstilladelse som au pair, side $12 / 20$

4. Udlændingeservice AUl: 12/20

5. Ibid. 14/20

6. Den internationale forskning omkring care migration og migranters husarbejde uden for Danmark har været relativt omfattende i de senere år, og den har beskxftiget sig med mange aspekter af denne form for migration ( $\mathrm{fx}$ Anderson 2000, 2002, 2007, Constable 1997, Glenn 1992, Hochschild og Ehrenreich 2002, Hondagneu-Soleto, P.(2001), Isaksen et al 2008), Lutz 2002, 2004, 2008, 2008, Parrenas 2001, 2002, Romero 1992. En mindre del af denne forskning har beskxftiget sig mere eksplicit med au pair-migration ( $\mathrm{fx}$ Anderson 2002, Cox 2007, Hess and Puckhaber 2004, Williams and Gavanas 2008).

\section{LITTERATUR}

- Anderson, Bridget (2007): A Very Private Business. Exploring the Demand for Migrant Domestic Workers in European Journal of Women's Studies Vol. 14(3).

- Anderson, Bridget (2002). Just another Job? The Commodification of Domestic Labour, in Ehrenreich, Barbara and Arlie Russell Hochschild (eds.). Global Woman. Nannies, Maids and Sex Workers in 
the New Economy. Metropolitan/Owl Books: New York.

- Anderson, Bridget (2000): Doing the Dirty Work. Zed Books 2000.

- Ardano, Janet M. (2003): Maternalism in Mistress-Maid Relations: The Philippine Experience, i Journal of International Women's Studies Vol 4, May 2003.

- Constable, Nicole $\left(20072^{\text {nd }}\right.$ ed-1997 $1^{\text {st }}$ edition): Maid to order in Hong Kong. Stories of migrant workers. Ithaca and London. Cornell University Press.

. Cox, Rosie (2007): The Au Pair Body, i European Journal of Women's Studies, Vol 14(3).

- Ehrenreich, Barbara and Arlie Russell Hochschild (eds.): Global Woman. Nannies, Maids and Sex Workers in the New Economy. Metropolitan/Owl Books: New York.

- Glenn, Evelyn Nakano (1992): From Servitude to Service Work: Historical Continuities in the Racial Division of Paid Reproductive Labor. Signs, Vol. 18, No. 1 pp. 1-43.

- Guiterrez-Rodriguez, E. (2010): Migration, Domestic Work and Affect. New York. Routledge - Hess, Sabine and Puckhaber Anette (2004): "Big sisters" are better domestic servants?!, i Feminist Review 77:65-78.

- Hondagneu-Soleto, P. (2001): Domestica. Immigrant workers cleaning and caring in the shadows of affluence. University of California Press.

- Lutz, Helma 2008 (ed.): Migration and Domestic Work. Ashgate.

- Lutz, Helma 2004: Life in the Twilight Zone: Migration, Transnationality and Gender in Private households. Journal of Contemporary European Studies, Vol 12, No 1, April 2004.

- Lutz, Helma: 2002: At your service Madame. The globalization of domestic service. Feminist Review.

- Parreñas, Rachel Salazar (2001): Servants of globalization. Women, Migration and domestic work. Standford University Press.

- Parreñas, Rachel Salazar (2002): The Care Crisis in the Philippines: Children and transnational families in the New Global Economy in Ehrenreich, Barbara and Hochschild, Arlie Russel (eds.) Global Women. Granta Books.

- Parreñas, Rachel Salazar (2008): The Force of Domesticity. Filipina migrants and globalization. New York University Press.
- Rollins, Judith (1985): Between Women: Domestics and Their Employers. Philidelphia. Temple University Press.

- Romero, Mary (1992, $2^{\text {nd }}$ ed 2002): Maid in the USA. New York. Routledge.

. Sollund, Ragnhild (2010): Regarding Au Pairs in the Norwegian Welfare State. European Journal of Womens' Studies.

- Stenum, H. (2008): Au Pair in Denmark. Cheap labour or cultural exchange. København. Foa.

- Williams, F and Gavanas, A. (2008): The intersection of Childcare Regimes and Migration Regimes: A Three-Country Study in Lutz (ed) (2008): Migration and Domestic Work. Ashgate.

\section{SUMMARY}

Au pair strategies in Danish host families private domestic worker or maternalistic micro-management

The concept of au pair is highly gendered, as it is historically rooted in a mixture of domestic work, family control and cultural education. The au pair system is a managed migration arrangement which has undergone a rather overlooked development in Scandinavia in recent years.

In this article the aim is to shed light on rationalities and subjectivities performed in strategies characterizing the relations between au pair employer and employee in the private space of the family household. Based on an empirical study conducted in 2007/2008 including interviews with au pairs and host families in Denmark, the relation between the au pair and the host family is analysed as gendered house work typically organised as a female-to-female relationship between the extra EU, ethnical minoritized, temporary migrant woman and the Danish, ethnical majoritized citizen.

Helle Stenum, ph.d. stipendiat

Ålborg Universitet 